\title{
Weed Management in Sesame ${ }^{1}$
}

\author{
Jason Ferrell and Pratap Devkota²
}

Sesame is a relatively new grain crop being grown in Florida. Although this crop provides many system benefits as a rotation partner, weed control is an important consideration. Currently, there are few herbicides registered for use in sesame (Table 1). Therefore, choosing a field with a history of low weed pressure will be helpful. Additionally, the use of stale seedbed techniques should be considered. A stale seedbed means that the soil is prepared a few weeks or months ahead of planting, then the weeds that germinate are controlled-with tillage or, preferably, with herbicides-multiple times prior to planting. This strategy will help to deplete the seedbank in the upper few inches of soil and result in emergence of fewer weeds during the cropping season.

\section{Rotational Considerations}

Sesame is highly susceptible to herbicides used in soybean, peanut, and cotton-such as Pursuit (imazethapyr), Cadre (imazapic), and Envoke (trifloxysulfuron). Sesame should not be planted in fields treated with these herbicides within the past 26 months. Rotational intervals vary depending on herbicide, soil type, and rate. Check rotational intervals specified in the label before planting. Field bioassays are highly recommended before you consider planting sesame in fields treated with the aforementioned herbicides.

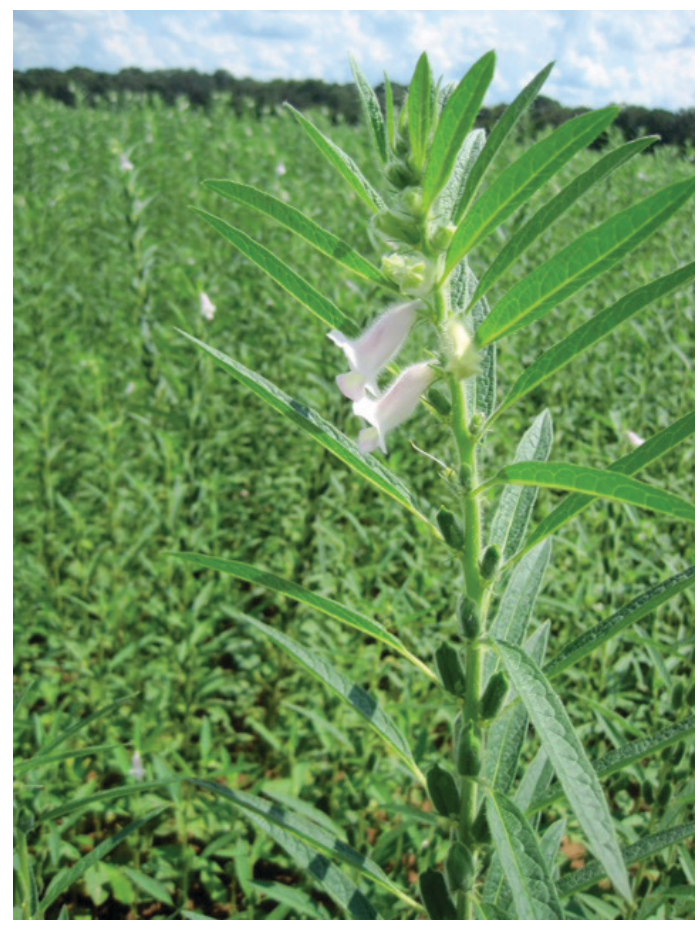

Figure 1. For sesame, weed control is an important consideration. Credits: Doug Mayo, UF/IFAS

1. This document is SS-AGR-392, one of a series of the Agronomy Department, UF/IFAS Extension. Original publication date June 2015. Revised April 2021. Visit the EDIS website at https://edis.ifas.ufl.edu for the currently supported version of this publication.

2. Jason Ferrell, professor, Agronomy Department, and director, UF/IFAS Center for Aquatic and Invasive Plants; and Pratap Devkota, assistant professor, UF/IFAS West Florida Research and Education Center; UF/IFAS Extension, Gainesville, FL 32611 . Originally written by Jason Ferrell; revised by Pratap Devkota.

The use of trade names in this publication is solely for the purpose of providing specific information. UF/IFAS does not guarantee or warranty the products named, and references to them in this publication do not signify our approval to the exclusion of other products of suitable composition.

The Institute of Food and Agricultural Sciences (IFAS) is an Equal Opportunity Institution authorized to provide research, educational information and other services

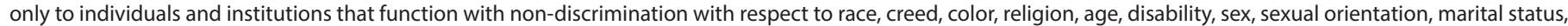

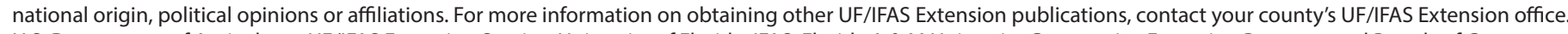
U.S. Department of Agriculture, UF/IFAS Extension Service, University of Florida, IFAS, Florida A \& M University Cooperative Extension Program, and Boards of County Commissioners Cooperating. Nick T. Place, dean for UF/IFAS Extension. 
Table 1. Herbicides for use in sesame.

\begin{tabular}{|c|c|c|c|c|}
\hline $\begin{array}{l}\text { Herbicide Active } \\
\text { Ingredient (Trade/ } \\
\text { Product Names) }\end{array}$ & $\begin{array}{l}\text { Mode of } \\
\text { Action } \\
\text { Group } \\
\text { (MoA) }\end{array}$ & $\begin{array}{l}\text { Application Rate } \\
\text { per Acre (total per } \\
\text { A/season or year) }\end{array}$ & $\begin{array}{c}\text { Reentry } \\
\text { Interval (REI) }\end{array}$ & Remarks \\
\hline \multicolumn{5}{|c|}{ Preplant Burndown } \\
\hline $\begin{array}{l}\text { glyphosate } \\
\text { (Roundup, or various) }\end{array}$ & 9 & $\begin{array}{l}0.5-1 \mathrm{lb} \text { acid } \\
\text { equivalent }\end{array}$ & $4 \mathrm{hrs}$ & $\begin{array}{l}\text { Glyphosate can be applied before, during, or after planting- } \\
\text { but prior to crop emergence. Can be tank-mixed with } \\
\text { preemergence herbicides but needs to be applied prior to } \\
\text { crop emergence. Do not apply if crop has emerged-it will } \\
\text { kill the crop. }\end{array}$ \\
\hline $\begin{array}{l}\text { paraquat } \\
\text { (Gramoxone } S L 2 E-2 \mathrm{lb} \\
\text { ai/gallon product) } \\
\text { or } \\
\text { (Paraquat } 3.0 \mathrm{~S}-3 \mathrm{lb} \text { ai/ } \\
\text { gallon product) }\end{array}$ & 22 & $\begin{array}{l}2-3.75 \mathrm{pt} \\
\text { or } \\
1.3-2.5 \mathrm{pt}\end{array}$ & $12 \mathrm{hrs}$ & $\begin{array}{l}\text { Paraquat can be applied before, during, or after planting- } \\
\text { but prior to crop emergence. Can be tank-mixed with } \\
\text { preemergence herbicides but needs to be applied prior to } \\
\text { crop emergence. Do not apply if crop has emerged-it will } \\
\text { kill the crop. }\end{array}$ \\
\hline $\begin{array}{l}\text { pyraflufen-ethyl } \\
\text { (ET) }\end{array}$ & 14 & $0.5-2 \mathrm{oz}$ & $12 \mathrm{hrs}$ & $\begin{array}{l}\text { For control of broadleaf weeds. Do not exceed } 5.5 \mathrm{oz} / \mathrm{ac} / \\
\text { yr. The addition of a crop oil adjuvant will improve control. } \\
\text { Planting can occur within } 1 \text { day of application. Can be mixed } \\
\text { with glyphosate to increase weed spectrum. }\end{array}$ \\
\hline \multicolumn{5}{|l|}{ Preemergence } \\
\hline $\begin{array}{l}\text { S-metolachlor } \\
\text { (Dual Magnum) }\end{array}$ & 15 & $1-1.3 \mathrm{pt}$ & $24 \mathrm{hrs}$ & $\begin{array}{l}\text { Effective on most annual grasses as well as pigweeds and } \\
\text { Florida pusley. Sesame response to Dual Magnum can be } \\
\text { variable, ranging from no injury to complete crop loss. } \\
\text { Although crop loss is not common, it does occur. Therefore, } \\
\text { Dual Magnum has an indemnified label. It can only be } \\
\text { obtained by going to www.farmassist.com. You must register } \\
\text { and accept the indemnification before the label can be } \\
\text { downloaded. Follow label directions to reduce the likelihood } \\
\text { of injury. } \\
\text { Although the risk of Dual Magnum injury to crops is real, the } \\
\text { risk of crop loss due to uncontrolled weeds is likely worse. } \\
\text { Therefore, using Dual Magnum will be necessary in most } \\
\text { fields. }\end{array}$ \\
\hline $\begin{array}{l}\text { ethalfluralin } \\
\text { (Sonalan HFP) }\end{array}$ & 3 & $1-1.5 \mathrm{pt}$ & $24 \mathrm{hrs}$ & $\begin{array}{l}\text { Sonalan HFP is registered for use in oilseed crops, including } \\
\text { sesame. It will control a variety of annual grasses and some } \\
\text { broadleaf weeds (such as Florida pusley). However, no } \\
\text { research has been conducted in Florida to determine sesame } \\
\text { crop safety. Use this product with caution. Sonalan HFP } \\
\text { should be applied } 45 \text { days ahead of planting to allow soil } \\
\text { concentrations to decline to levels that are non-injurious to } \\
\text { sesame. }\end{array}$ \\
\hline \multicolumn{5}{|c|}{ Postemergence } \\
\hline $\begin{array}{l}\text { sethoxydim } \\
\text { (Poast) }\end{array}$ & 1 & $1.5-2.5 \mathrm{pt}$ & $12 \mathrm{hrs}$ & $\begin{array}{l}\text { Effective on most annual grasses, but weaker on perennial } \\
\text { grasses such as common bermudagrass. Do not exceed } 5 \\
\text { pt/ac/yr. All applications should contain either a crop oil } \\
\text { concentrate or methylated seed oil, not a surfactant. Do not } \\
\text { harvest within } 60 \text { days of application. } \\
\text { Poast Plus is not registered for use in sesame. }\end{array}$ \\
\hline $\begin{array}{l}\text { clethodim } \\
\text { (Select Max) }\end{array}$ & 1 & $9-16$ oz & $24 \mathrm{hrs}$ & $\begin{array}{l}\text { Effective on most annual grasses and more effective on } \\
\text { perennial grasses than Poast. Apply with a non-ionic } \\
\text { surfactant. To control bermudagrass, make a second } \\
\text { application } 14 \text { days after the first. Do not exceed } 64 \text { oz/ac/yr. } \\
\text { Do not harvest within } 14 \text { days of application. } \\
\text { Do not apply during flowering or severe crop injury will } \\
\text { result. This product should be used early in the season, prior } \\
\text { to flowering, or at the end of the season when flowering has } \\
\text { ceased. }\end{array}$ \\
\hline
\end{tabular}




\begin{tabular}{|c|c|c|c|c|}
\hline $\begin{array}{l}\text { Herbicide Active } \\
\text { Ingredient (Trade/ } \\
\text { Product Names) }\end{array}$ & $\begin{array}{l}\text { Mode of } \\
\text { Action } \\
\text { Group } \\
\text { (MoA) }\end{array}$ & $\begin{array}{l}\text { Application Rate } \\
\text { per Acre (total per } \\
\text { A/season or year) }\end{array}$ & $\begin{array}{c}\text { Reentry } \\
\text { Interval (REI) }\end{array}$ & Remarks \\
\hline $\begin{array}{l}\text { clethodim } \\
\text { (various suppliers) }\end{array}$ & 1 & $6-8 \mathrm{oz}$ & $24 \mathrm{hrs}$ & $\begin{array}{l}\text { Effective on most annual grasses and more effective on } \\
\text { perennial grasses than Poast. Apply } 6-8 \text { oz/ac with a crop } \\
\text { oil adjuvant. To control bermudagrass, make a second } \\
\text { application } 14 \text { days after the first. Do not harvest within } 14 \\
\text { days of application. } \\
\text { Do not apply during flowering (see statement for Select Max). }\end{array}$ \\
\hline \multicolumn{5}{|c|}{ Harvest Aid } \\
\hline $\begin{array}{l}\text { glyphosate } \\
\text { (Roundup Weathermax) }\end{array}$ & 9 & $32 \mathrm{oz}$ & $4 \mathrm{hrs}$ & $\begin{array}{l}\text { Only use Roundup Weathermax (which has a supplemental } \\
\text { label for this use) or other glyphosate products that specify } \\
\text { use as a harvest aid in sesame. } \\
\text { Apply when } 50 \% \text { of sesame leaves are brown to terminate the } \\
\text { crop for harvest. }\end{array}$ \\
\hline
\end{tabular}

